\title{
実世界に情報を宿す拡張現実型 情報提示手法の研究
}

Augmenting the Real World for Ubiquitous Information Environment

苗村 健 $^{\dagger}$

Takeshi Naemura

\section{Summary}

情報技術の進展に伴い, 我々は膨大な情報に囲まれなが ら生活をするようになってきた.このため, 必要な情報に だけ効率的にアクセスできる手段をいかにして構築してい くかが重要な技術課題になっている，本論文では，実世界 中の様々なところに，人に見えない形・聞こえない形で情 報を「宿す」ことによって, 生活環境に密接した情報環境を 実現する情報提示手法について述べる．これは，Ubiquitous Computing における invisible な情報環境の実現を目 指した試みである．従来の「位置計測に基づくコンピュー ティング」に比べ，この「物体に情報を宿す」アプローチは， シンプルな構成によって原理的に高速で多人数でも容易に 利用できるという特徵を有する. 具体的には, 超音波を使っ て空間的な定位が可能な形で音声情報を伝達するu-soul と, プロジェクタ映像の中に情報を埋め込む PVLC プロ ジェクタについて紹介する

\section{Lley worls}

ユビキタス情報環境, 実世界指向インタフェース, 拡張現 実感

\section{1.まえがき}

Mark Weiser が提唱した Ubiquitous Computing の概 念 [1]は, コンピュータが我々の生活空間に遍在し，区 別がつかないほどひっそりと日常生活に織り达まれてい く未来像を我々に示してきた。通信分野において，いつ でもどこでもネットワークにアクセスできる環境の整備 に重点が置かれてきたのも，この文脈に整合した展開で

\section{†東京大学大学院情報理工学系研究科, 東京都}

Graduate School of Information Science and Technology, The University of Tokyo, Tokyo, 113-8656 Japan
あったといえよう．

ここで, Ubiquitous Computing のもう一つの側面に 着目する. Mark Wiser は, “invisible”という言葉を強 調していた。あからさまに目立つ存在であっては，真に 日常生活に溶け込んだことにはならないのである。それ でいて，あらゆる場面にコンピュータが遍在している姿 は，古来の日本で「万物に神が宿る」と信じられてきたと いう話を連想させる．前田らによる「妖精・妖怪の復権」 という考え方 [2]も，これに通じる.

そこで本論文では，「万物に情報を宿す」という情報提 示のあり方を探る筆者らの試み［3］を紹介する。この前 提として，ネットワークなどを通じて，情報そのものは 至るところに届いているという状況を想定する。これは 既に実現されつつある前提条件であり，むしろ，情報が あふれるままに人々を圧倒していることの方が問題であ ろう。この情報の洪水を止めることはできないまでも, 普段はこっそりと実世界の中に宿っていて, 必要なとき にだけそっと手を差し伸べるような枠組みが，今後ます ます必要になってくる，この意味において「情報を宿す」 とは, 単に情報が到達している状態を指すものではない. むしろ，人々が情報を受け取る最後のアクセス手段に特 徵を有する，さりげない情報提示手法と位置づけていく ことができる。

このためには，例えば，個々の物体に宿された情報が その物体から発せられていることを，人々がごく自然に 体感・理解できる仕組みが重要であると考えられる。こ れは，実世界を情報的に拡張する拡張現実感 (Augmented Reality) や実世界指向インタフェースの研 究分野における課題でもある。しかしこれまで, 物体や ユーザの位置計測に重きを置き, その計測結果に応じて 情報を加工したり, サーバから別のチャネルで情報を伝 送したりする研究がしばしば見受けられてきた。これは 「位置計測に基づくコンピューティング」であって, 物体 


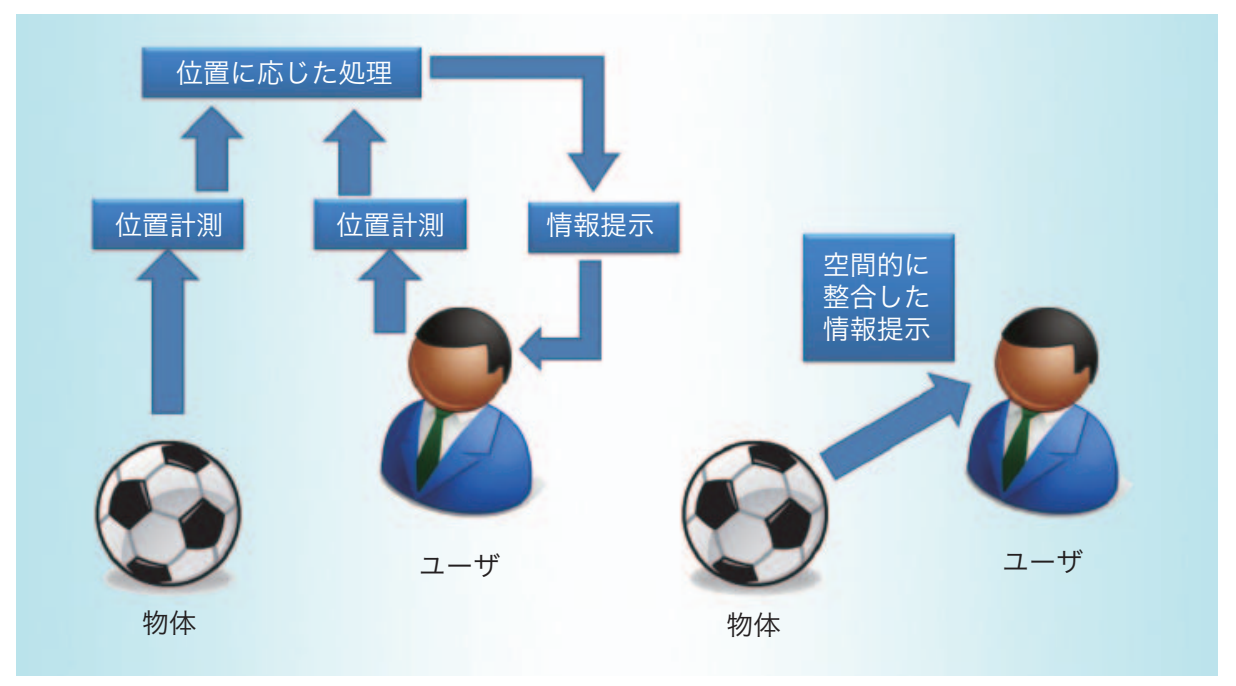

図 1 位置計測に基づくコンピューティングと物体に情報を宿すアプローチ

そのものに情報を宿すという立場とは異なるものである (図 1)。筆者らは，個々の物体に宿された情報を直接受 信するだけで，明示的な位置計測を行わずとも，空間的 な整合性を保った情報提示が可能になる仕組みの実現を 目指している.

「位置計測に基づくコンピューティング」と「情報を宿 すアプローチ」では，例えば，以下のような違いが期待 される，前者では，位置計測の精度・計算コスト・遅延 などが問題になるが，伝送する情報の量は別のチャネル を使用することで自由に設計できる，特に，不特定多数 で同時に使用するためには，人数に応じた規模のシステ ムをあらかじめ設計しておくことが必要になる。一方， 後者では，物体に宿された情報を同時に多人数で受信す ることを可能にすることで，人数に対する自由度は高く なるが，情報量は通信の方式によって制限されることに なる，また，後者の方式で位置情報を宿すことによって， 前者の枠組みを取り入れていくことも可能であると考え られる。

以下では，「情報を宿す」ための具体的な例として，聴 覚と視覚のそれぞれにおいて, 聞きたい人にだけ聞かせ, 見たい人にだけ見せる仕組みを紹介する。

\section{2．実音場を拡張する情報提示手法}

\section{1 実世界に音声情報を宿すことの意義}

博物館などにおいて，説明文を掲示するだけでなく， 音声によるガイドが重宝されているように，聴覚は効率 的な情報伝達手段である。しかし，あふれる情報をすべ て音声で流していたのでは，それを必要としない人に とっては，騒々しいだけである。

そこで，聞きたい人にだけスポット的に音を伝える技 術の研究が進められている。トーキングサイン [4]では,
音を赤外光に載せて伝送することで，受光端末をもった ユーザが選択的に聞きたい音声情報にアクセスすること を可能にしている. 受光端末を小型化し, 耳元のイヤホン に設置する CoBIT [5］では，人の振舞いと音声情報の 選択動作が自然に連動するようになっている.イヤホン 型のシステムとしては, そのほかに, 高音質化を実現し たVoiceubique [6]がある。また, Visual Resonator [7] では, 赤外光の指向性を積極的に利用することによる円 滑なコミュニケーションの支援を提案している.しかし， これらのシステムには共通の問題点がある。すなわち, 音が耳の中 (若しくは頭の中) から聞こえてくるように知 覚され，実世界のどこに情報が宿っているのかを直感的 に理解することが難しいという点である。これはちょう ど, イヤホンで音楽などを聞いているのと同様の状況で ある。

一方，我々は日常生活において，どの方向から，どれ くらい離れたところからその音が聞こえてくるのかを, およそ把握することによって，様々な活動をしている. 「こちらへどうぞ」と聞こえれば，声のする方向に歩き出 す、頭の中に音が定位する方法では，方向を伝えるため には，「こちら」では意図が伝わらず，より詳細な説明を 要することになる，なお，Visual Resonator では，音は 頭の中で聞こえることになるが，ユーザの向いている方 向から発せられる情報に選択的にアクセスすることがで きるため，音が聞こえてくる方向を知ることは可能に なっている，ただし，本来，聴覚が視覚よりも優れてい る点は, 前方に限らず様々な方向に対して注意を払うこ とができる点にある，正面を向いていなくとも，適切な 方向から音が聞こえてくるためには, 音が頭の中ではな く, 三次元空間中に定位して聞こえる仕組みが必要とな る. 同様の問題意識から, Surround CoBIT [8]では, 左右の耳に音量差を与えることで, 音の聞こえてくる方 
向を判断できる仕組みを提供している. しかし, 三次 元空間中に音が定位するためには，両耳に音波が届く 時間差も重要な要因として挙げられ, 自然な定位感を 与えるには至っていない.

頭の中でなく，三次元空間中に音を定位させる方法 としては,バーチャルリアリティの分野で HRTF (Head Related Transfer Function）を用いた手法が開発されて いる。これは, 人と音源の位置関係を計測し, それに 応じて音波の各周波数成分がどのように空気中を伝搬 するのかを計算し尽くして，両耳に提示する手法であ る、膨大な計算量を要するため, 遅延の問題が指摘さ れてきたが, 近年, 実時間による演算が可能になりつ つある.しかし, HRTF には個人差があり [9], 個人ご とにHRTFを事前に計測しておくことが望まれるな ど，不特定多数で容易に利用するにはまだ課題が残さ れている。これは典型的な「位置計測に基づくコン ピューティング」として位置づけられる.

\section{2 提案手法の概要}

以上の状況を踏まえ, 筆者らは, 下記の三つの条件 を満たす新たな手法を提案した $[10]$.

・ヘッドホンをした人にだけ

・ 人数によらずに

・ 三次元空間中に定位した音を聞かせる

これを実現する手段として，超音波に着目した。先 行研究が光を媒体としていたのに対して, 超音波を媒 体として利用し, 超音波が空気中を伝搬する際に生じ る時間差や音量差によって定位感を与える方法である。 u-soul (Ultrasonic/Ubiquitous-SOUnd Localization interface）と名づけられた本システムの詳細は, 文献 [11]を参照されたい。ここではその概要をまとめる。

基本原理は，図 2 のとおりである。まず，可聴音 (20 $\mathrm{kHz}$ 以下の音波）を, FFT で周波数領域に変換して超
音波領域に変調し, IFFTで時間波形に戻してから超音 波スピーカで出力する。 そして, 超音波マイクで集音 された波形を, FFTで周波数領域に変換して可聴域に 復調し, IFFTで時間波形に戻してからへッドホンで提 示する.

図 3 に, システム構成図を示す。ヘッドホンに超音 波マイクを装着し, 両耳の位置で超音波を集音して, ヘッドホンから復調された可聴音を聞かせる。超音波 の空気中での伝搬を経て，左右の耳に適切な時間差と 音圧差が現れる。この時間差と音圧差を保ったまま可 聴音に変調することで，人はどの方向から音が聞こえ てきたのかを知覚することができる。

超音波スピーカの位置に宿っている情報は, 超音波 マイクを装着したユーザだけがアクセス可能であり， コンピュータによる位置計測などを行わなくても, ユー ザの耳に届く段階でその位置をユーザ自身が知覚する ことができる．超音波という形態で実空間を情報で満 たしておくアプローチであるため, 不特定多数のユー ザが同時に利用することが可能になっている.

なお実装には, 野生動物や海中でのコミュニケー ション用途に開発されてきた超音波デバイスを活用す ることができる。 また, 関連する技術として, 強力超 音波の非線形ひずみによる自己復調を利用した超指向 性スピーカ [12］を挙げることができる。これは，特定 の領域に限って，すべてのユーザに音を聞かせるため の指向性の強いスピーカであり，様々に実用化が進ん でいる，u-soulでは，自己復調が起こらない超音波強 度を用いることにより, 超音波マイクで集音した場合 にのみ可聴音を再生し, 音像定位に利用している。

\section{3 聴 取 実 験}

超音波は赤外光などに比べれば, 可聴音に近い伝搬 特性を有している。しかし, 超指向性スピーカやサイン

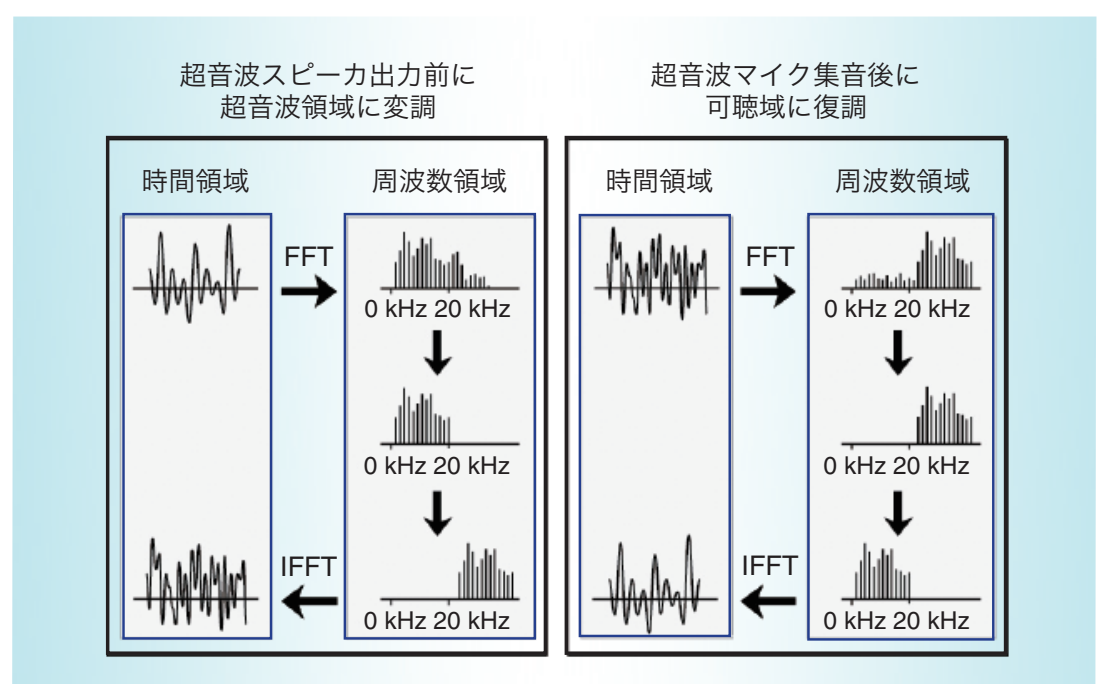

図 2 音情報の変復調 


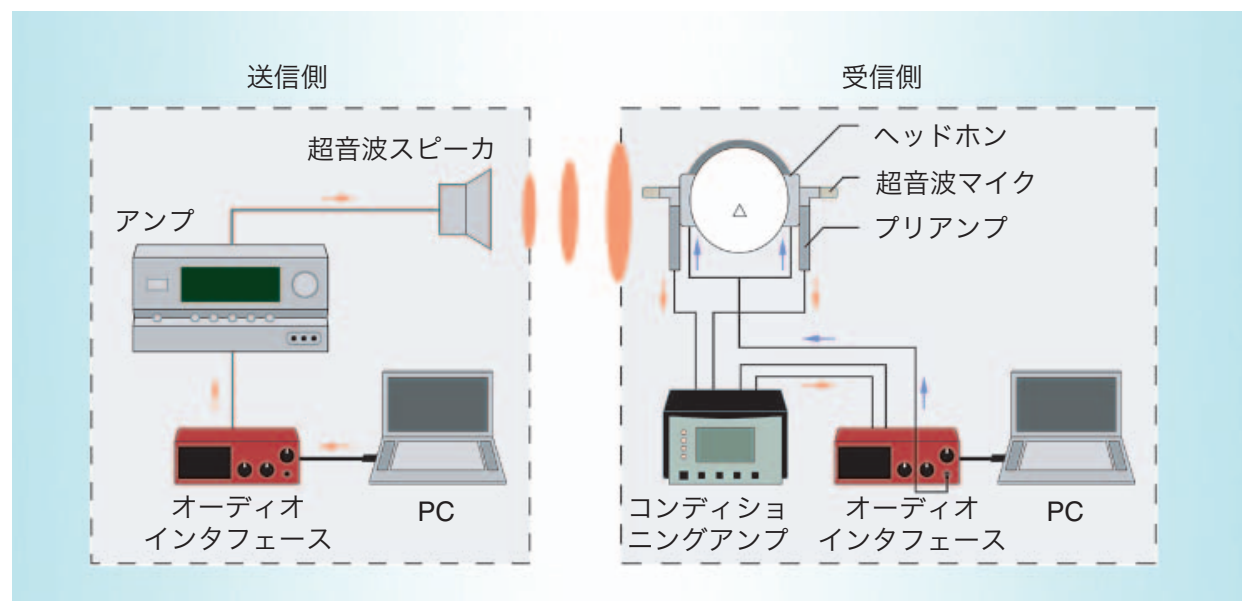

図 3

システム構成

ポスト [13]など，超音波を用いたシステムでは，その指 向性を積極的に利用するものが多い. 可聴音に比べて指 向性の強い超音波を用いることで, 音像の定位感が失わ

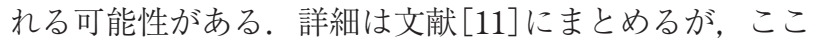
では聴取実験の概略を紹介する。

まず，両耳に届く音圧について調べた。波長の短い超 音波では，Acoustic Shadow が生じやすくなる。すなわ ち, 可聴音であれば頭部を回り込んで両耳に到達する音 も，超音波では直進してしまい，反対側の耳まで到達す る量が減ってきてしまう。定量的な評価により，可聴音 を直接聞く場合に比べ，超音波を用いる方法では左右の 音圧差が大きくなる傾向が確認された。一方で，両耳時 間差に関しては原理的に大きな差は生じないと考えられ る、 u-soul は, 両耳時間差を保ちつつ, 両耳音圧差が強 調された形で音像を提示するシステムであるとみなすこ とができる。

次に，空間的な音像定位感について，定性的に評価し た。具体的には，超音波スピーカをユーザが保持して移 動させながら，その聞こえ方に関するアンケート調査を 12 名の被験者を対象に行った。

・音がスピーカと一緒に動いているように感じたか

・音の移動は自然に感じられたか

・音はどこから鳴っているように聞こえたか(頭の外： 5 , 頭の中 : 1)

という質問に対して，5段階評価において平均でそれぞ れ，4.75，3.50，3.42 という結果になった。いずれも中 間スコアの 3.0 を上回っており，特に音源位置の追従性 の高さが確認されたが，頭の外から自然に聞こえてくる ようには必ずしも感じられていないことが分かった。こ れは, 上記の両耳音量差の影響と考えられる. 本実験に より，少なくとも，どこから聞こえてくるかを直感的に 理解することは可能になっているといえよう.

最後に，2台の超音波スピーカを用いて，どちらから 音が聞こえてくるかの判別実験を行った。その結果，可

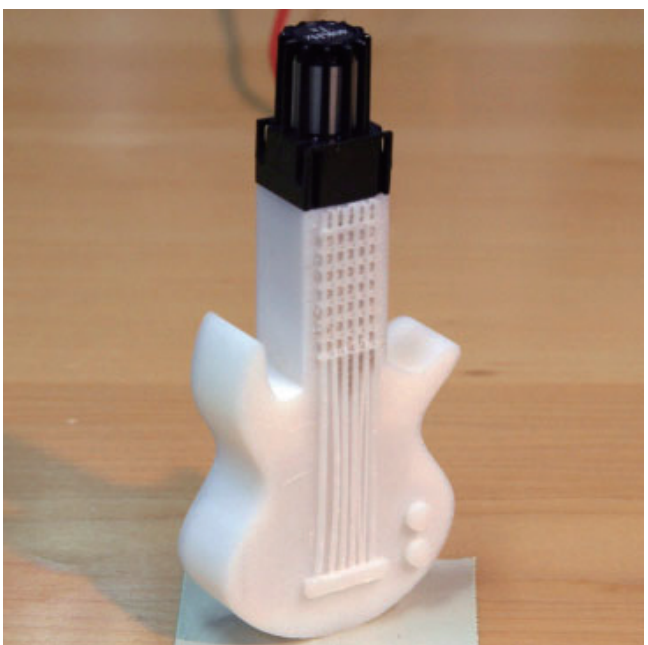

図 4 楽器型オブジェクトから奏でる音楽

聴音のホワイトノイズを超音波で伝送した場合には, $100 \%$ の正答率が得られた. 単一周波数のサイン波(単音) の場合には $65 \%$ まで低下するが，音声など帯域の広い 情報を提示する場合には，実用に堪え得るものと判断さ れる。

\section{4 アプリケーション}

u-soul のアプリケーションとして，いくつかの実装を 進めてきた[14].

図 4 に, 楽器の形をしたオブジェクトに超音波スピー カを装着した例を示す。このようなオブジェクトを複数 用意して，楽曲のそれぞれのパートを超音波で奏でる. システムを装着したユーザは，それぞれの楽器から音が 聞こえてくるという感覚をもちながら, 時にはその位置 を動かしつつ, 合奏を聞くことができる。これは, 楽器 オブジェクトに楽曲の演奏情報を宿した例として位置づ けられる。

また, 事前に録音した楽曲を演奏するだけでなく, ユー ザが自ら演奏するシステムも考えられる。例えば，サイ レントドラムへの応用である。一般に，サイレントドラ 
ムでは, 圧電センサなどを内蔵したパッドをユーザがた たくと，ドラム音がヘッドホンで提示される．周囲に迷 惑をかけることなく, 自分だけが自分の演奏を聞くこと ができるシステムである。このサイレントドラムにおい て，パッドの位置に超音波スピーカを仕込むことで，自 分がたたいたパッドの位置からドラム音が自分だけに聞 こえてくるシステムを実装した。

以上，音楽を題材にしたアプリケーションを二つ紹介 した. 続いて音声に関するアプリケーションに移る前に, u-soul のもj一つの重要な機能である多重化について述 ベる.これは, 超音波をいくつかの带域に分けることで, 一つの超音波スピーカから同時に複数チャネルでの伝送 を行う機能である。この方式によって，ユーザは聞きた いチャネル(超音波带域)の音を選択的に聞くことが可能 になる。

例えば，展示物の解説などの場面において，二つの人 形が会話をするような，すなわち，片方が質問をして， もう一方が答えるような演出を考える。ヘッドホンをし ていない人には，人形たちの会話は聞こえない.ヘッド ホンをしてチャネル 1 を選ぶと日本語で, チャネル 2 で は英語で人形たちが会話をしているように聞こえる。人 形に超音波スピーカを仕込むことによって，実際に人形 が会話をしているような感覚を与えることができる。ま さに，人形に音声情報を宿す試みである。図 5 にその様 子を示す。

その他の例では, 館内案内システムに利用すると, チャ ネル 1 を選んでいる人には, 会議室にたどり着くまで, 各所で「こちらにどうぞ」と聞こえる方向に歩けばよく， チャネル 2 を選んでいる人には, 食堂への道のりが聞こ えてくるようなシステムを構築することができる. 道を 知っている人は, ヘッドホンをしなければ何も聞こえな い.これは，廊下に道案内情報を宿す試みとして位置づ けられる，5人の被験者を対象に，指定の部屋までたど り着くことができるかを実験した結果，全員が目的を達

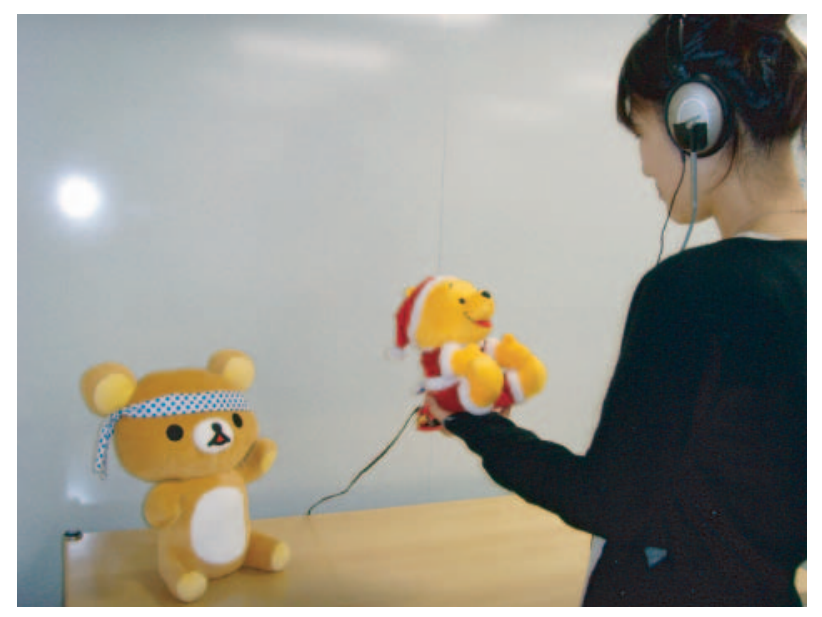

図 5 人形たちの会話
成することができた，図 6 にその様子を示す.

最後に, 複数ユーザによる会話システムを構築した。 これは，周囲が騒々しく，会話が聞き取りにくい状況に おいて, それぞれの音声を超音波に変換して, 超音波マ イクを装着した相手に自らの音声を送る仕組みである. ヘッドホンに可聴音(周囲の騒々しさ)を遮る仕組みを設 けることで，ユーザは超音波から復調された可聴音のみ に耳を傾けることが可能になる。ユーザごとに超音波带 域を割り振ることで, ユーザは会話の相手を選択するこ とができる。

\section{5 今後の課題}

超音波スピーカを装着した物体に音情報を宿す仕組み について概説した。望まないユーザには何も聞こえず， 必要とするユーザには物体から音が聞こえてくるように 知覚される.いくつかのアプリケーションの実装を通じ て，その有効性を確認した。今後は，超音波の指向性の 問題を低減する手法や，音質を改善する方法について検 討する。

なお，原理的に，超音波スピーカ以外に，超音波を発 する機器が近くにある場合には，そのノイズまで可聴音 に変換されて聞こえることになる。これまでの実験にお いては，ほとんど問題になることはなかったが，設置す る場所に応じて，使用する超音波帯域を調整するなどの 対策が必要になる場合があると考えられる。

\section{3. プロジェクタ映像を拡張する情報提示手法}

\section{1 プロジェクタ映像に情報を宿すことの意義}

音像に限らず，様々な情報を実世界の物体に付与する (宿す) 仕組みとして, 電子的な夕グや何らかのマーカを

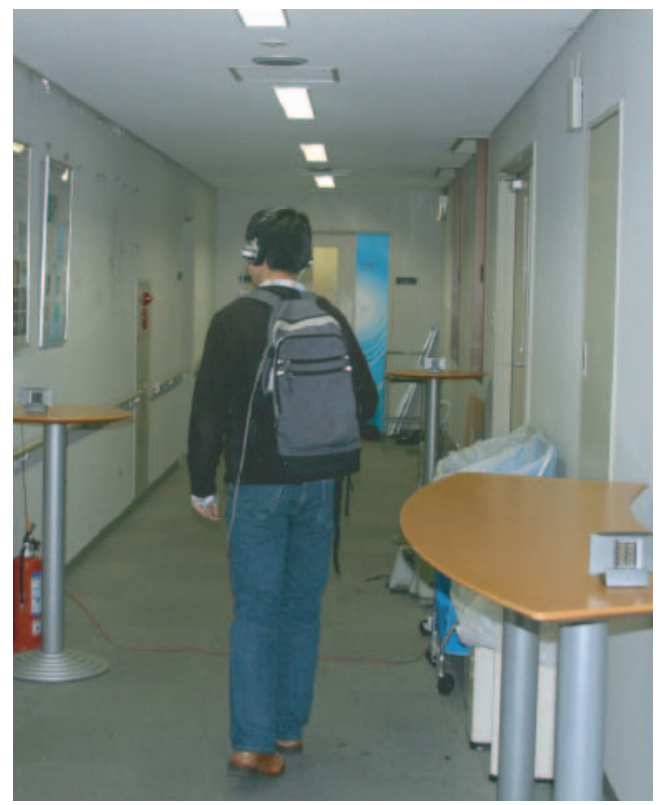

図 6 道案内システム 
用いる方法が利用されている.

電子的なタグとしては, RFID (Radio Frequency Identification）がある。 JR 東日本の Suica などは, カー ドに RFID タグを内蔵することで情報を付与し, 人々が RFID リーダにそれをかざすことで情報の読出しを行う 例である。逆に, RFID タグを環境中に遍在させておい て，その中でRFIDリーダをもったユーザが歩き回るこ とで，ユーザの位置を認識する方法も検討されている [15]．これは環境中に情報が宿る例として位置づけられ る。また，空間中に配置された多数の RFID 夕グに向け てプロジェクタ光でパターンを投影することで, RFID 夕グの位置情報を取得する研究もある [16].このような 電子的な夕グを用いる方法は, 実用化が進み, 大変有望 なアプローチである，ただし，事前にタグを埋め込む必 要があるという制約がある.

一方，バーコードや QR コードなどは，印刷するだけ で安価に大量に作ることができるため, 我々の生活に広 く浸透している。杂誌やポスターの中に印刷されたコー ド(マーカ)という形で宿っている情報には, 携带電話な どを用いてアクセスすることができる。このようなマー カに関する研究としては, 安定して認識可能な方形の二 次元マトリックスコード [17] が提案されている. また, 一般の文字や画像もマーカとして利用する ARToolKit [18]は，拡張現実感研究の基盤技術として広く利用され ている。しかし，機械にとって意味のあるマーカでも， 人の目には目障りであるという問題がある。 そこで, 半 透明の再帰性反射材 [19]や, 赤外光のみを遮断する素材 [20]若しくは赤外光のみを反射する素材 $[21]$ などを用い ることで, 不可視な透明マーカを実現する方法が提案さ れている.

一方, 印刷したマーカが静的なのに対して, 動的に変 化する情報提示を実現する試みとして, プロジェク夕映 像にマーカを表示する Display-Based Computing [22] の研究が進められている. 更に, 不可視かつ動的なマー カ提示の研究としては, 赤外光プロジェク夕と赤外線受 光デバイスを用いる方法が提案されている [23]～[25]. 一般に, 市販されているビデオカメラは赤外光領域まで 感度があるため, 赤外光で投影された情報へのアクセス は比較的容易に行うことができる. また, 投影された赤 外光を, 電子的な手段ではなく, 赤外可視変換素材を用 いて直接可視光に変換する試みもある $[26]$.

以上のような背景を踏まえ, 筆者らは, 不可視かつ動 的な情報を, プロジェク夕映像の中に宿す手法を提案し てきた [27], [28].これは, マーカという形式に限定せ ずに,より一般的な通信をプロジェク夕映像の画素単位 で行う試みである。別の言い方をすれば，例えばXGA 解像度のプロジェク夕を用いる場合, $1024 \times 768$ 個の 画素がそれぞれ独立した通信チャネルになることを意味
しており,プロジェクタで映像を投影した領域に多数の 送信機を宿らせる仕組みと位置づけることができる。こ の手法のメリットは, プロジェクタで投影された可視の 映像と空間的に整合した情報発信を行うことができる点 にある。

このような, 人に見える光の中に，見えない形で情報 を宿す技術としては, 可視光通信 $[29]$ の先行研究がある. 照明や信号機を高速点滅させることで, 時間軸方向に情 報を宿す技術である。しかし，LEDで照らされたエリ アに一様に情報が提供されるため, 空間中の位置に応じ て細かく情報を分けて提示することはあまり検討されて いない. 多数の LED を平面上に配置することによって, 空間分割された情報を提示する試みもあるが，まだ解像 度の高い映像を人に見せるというレベルには達していな い[30]. 筆者らの試みは, プロジェク夕映像の画素ごと に可視光通信を行う手法であり, PVLC プロジェクタ (Pixel-level Visual Light Communication Projector) と 名づけた。

\section{2 提案手法の概要}

具体的には, DMD（Digital Micro-mirror Device）を 用いた映像プロジェクタを改造して実装した. DMD は, 微細な鏡を高度に集積したチップであり，米国 Texas Instrument 社が DLP (Digital Light Processing) プロ ジェクタの基盤技術として開発したものである. 1 画素 につき一つの微小鏡が対応しており, 鏡の角度によって, 光源からの光をスクリーン方向に導くか, 吸収材方向に 導くかを制御する、鏡を高速制御することによって, プ ロジェクタ映像の諧調的な表現を実現している。この高 速性を利用して, 同期した高速メガネにだけ別の映像を 見せる Snared Illumination [31]，パターン光やマーカ を同期した高速カメラに読み取らせる方法 [32]，［33]な どが提案されている. また, 形状計測 [34], 立体ディ久 プレイ [35]，カメラ[36]など様々な分野への応用 [37]も 検討されている，筆者らは，これに可視光通信の枠組み を導入し，映像と空間的に整合した「情報を宿す」技術と して応用していく．なお，DMDに代わるデバイスの開 発が各社で進められて扔り, 高速性を有するデイスプレ イ技術一般で実装可能な, デバイスに依存しない議論を 展開していくことも可能であると考えている.

図 7 にシステム構成図を示す。DMDの制御には, DMD Discovery（Texas Instrument社製）及びALP (ViALUX 社製)を用い, USB を通してコンピュータか ら制御する [38]。プロジェクションされた映像の上に何 らかの受光端末をかざしたり, 映像を高速カメラで撮影 したりすることで, 映像の中に宿っている情報にアクセ スすることができる。映像投影は，正面投影の場合には 端末が映像を遮ることになるが, 背面投影にしておけば この問題は生じない. 


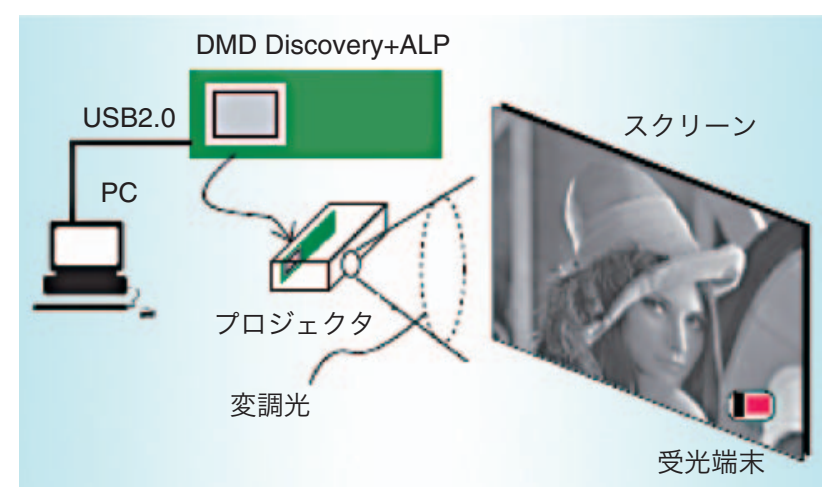

図 7 システム構成図

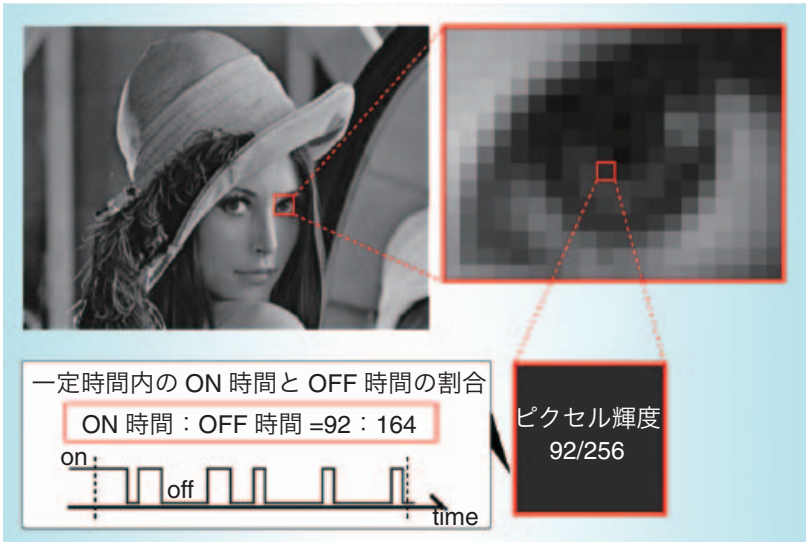

図 8 情報を宿す方法

各画素に時間軸方向に情報を載せる方式を図 8 に示 す. 各画素は表示する映像に応じた輝度值を有しており， これは一定時間内において鏡が ON（スクリーン方向） の状態と OFF（吸収材方向）の状態の時間的な比率に よって制御される，人に見える映像は，この時間的な比 率だけで決まる。時間積分した結果だけが映像の輝度と して人には知覚されるのである。すなわち，この比率を 保ったまま，点滅する順番を入れ換えても，人には知覚 されない，一般の DLP プロジェクタでは，この順番が 一律に規定されている。 そこで，この順番を意図的に制 御することによって, 点滅の順番を機械にだけ見える情 報として利用することができる。

\section{3 アプリケーション}

提案手法は，映像と機械の新たな関係を生み出し，実 世界に抢ける様々な情報提示を可能にする，宿っている 情報を読み出す手段としては，以下の二つの方法が考え られる。

・プロジェクタ映像の上に受光端末をかざす

・プロジェク夕映像を離れた位置から高速カメラで撮 影する

図 9 に，受光端末をかざす例を示す。日本地図の映像 の上に端末をかざすと，そこに点滅パターンとして宿っ
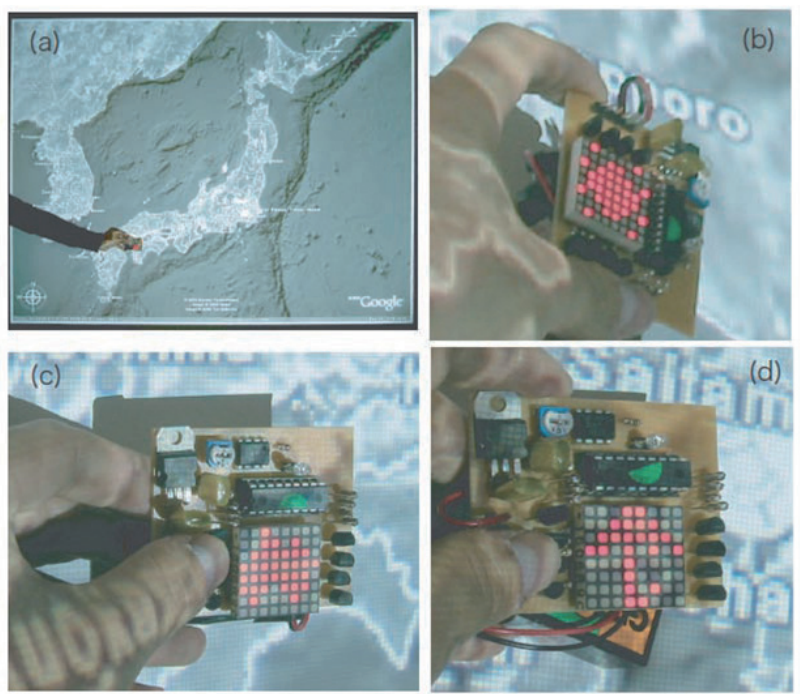

図9 天気予報

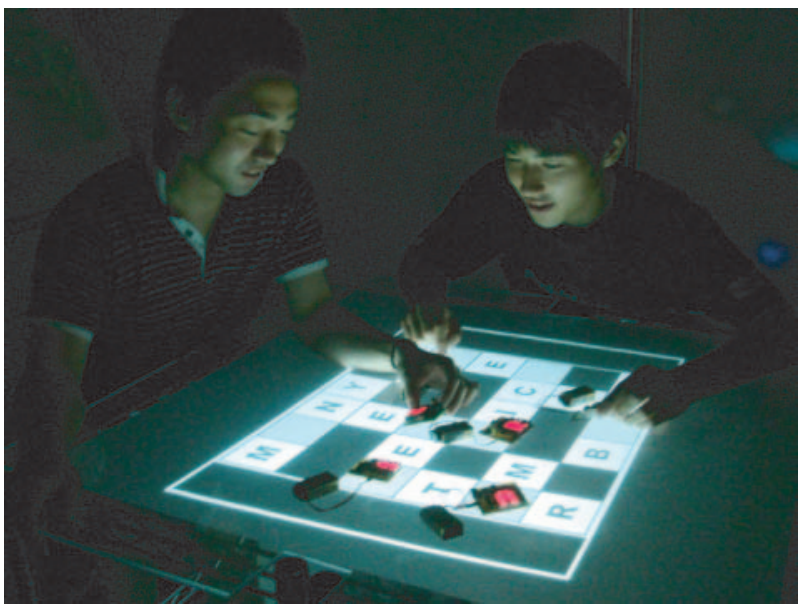

図 10 EmiTable

ている天気情報(ピクトグラム)が表示される。この例に とどまらず，原理的に，映像の内容と直接リンクした情 報を提示することができる。受光端末は，ホトセンサに 届く光の点滅から情報を読み取るだけのシンプルな構成 であり, 三次元的な位置計測などの高度な計算は行って いない.このため, 動作は極めて高速である。また，プ ロジェクタ自身が映像と同時に付加情報を投影している ため, 設置の際に複数の機器の校正をして位置を合わせ てといった手間が一切かからない点に特徴がある。通常 のプロジェクタと同様に，設置して投影を開始すれば， 既にそこに別の情報が宿っているのである.

PVLCプロジェクタを水平スクリーンの下に設置し, 背面投影によるテーブル型ディスプレイを構築した例を 図 10 に示す。テーブル面の各位置から個別の情報を放 出 (emit) しているという意味から, EmiTable と名づけ た [39]. EmiTableでは，水平なテーブル面に複数の受 光端末を配置することができる.PVLCプロジェクタ 
は, 原理的に, 全画面に対して常に情報を宿しており, 受光端末の位置や数に応じた処理は必要としない.また, 受光端末は独立に動作しており, 複数の受光端末を同時 にテーブル上に配置しても，遅れなどが生じることはな い.

図 11 に，クロスワードパズルの例を示す．グレーの 方形領域に当てはまるアルファベットを考え, そこに受 光端末をかざすと, 正解のアルファベットがピクトグラ ムとして表示される，答はそこに宿っていたのである。

このほかの例としては, 端末を映像上で滑らかに動か すと，位置に応じたアニメーションが見えるアプリケー ションなどを実装している。また，ピクトグラムのよう な視覚的な情報に限らず，一般的な情報を扱うことがで きる枠組みであるため

・映像とリンクした音を奏でる

・等高線画像で凹凸形状ディスプレイを制御する

・磁場などを制御して卓上物体の挙動を操作する

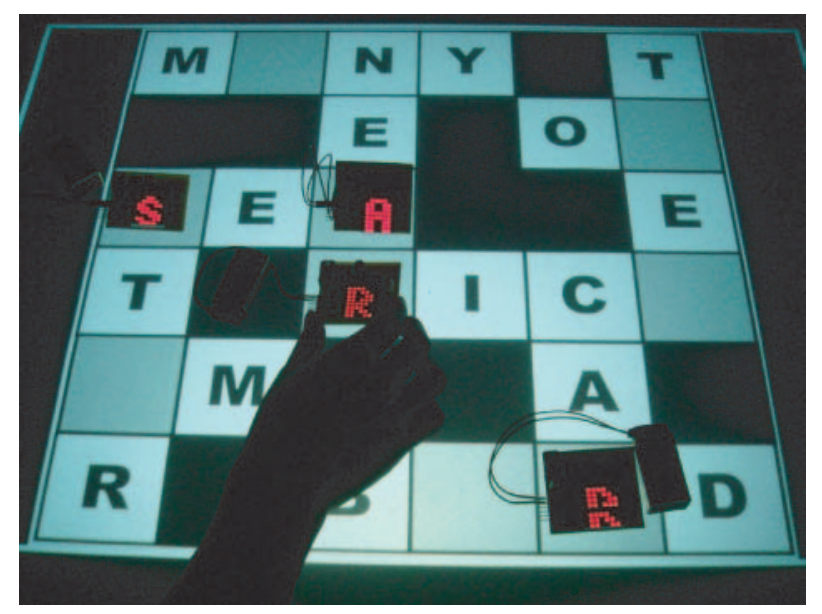

図 11 クロスワードパズル
などの機能を実装することが考えられ，ヒューマンイン タフェースやメディアアート作品など, 様々な応用分野 を開拓していくものと期待される.

図 12 には, 受光端末を映像の上にかざすのではなく, 離れた位置から高速カメラで読み取る例を示す。人の目 には単なる地図にしか見えていないが, 高速カメラを装 着したハンディな小型 PC 越しにその地図を見ると, 付 加情報がスーパインポーズされて表示される. カメラを 移動させたりズームしたりしても, スーパインポーズさ れる情報がずれることはない. 重要なのは, PVLC プロ ジェクタと高速カメラの間の位置合せや三次元位置計測 などを行っていない点にある，高速カメラによって撮影 される映像の中から, 付加情報を受信し, その位置に受 信した情報を表示するという単純な仕組みになっている からである。 これを可能にしているのは, PVLCプロ ジェクタが, 無数の送信機を空間的に投影・配置するよ うな形で実世界を情報的に拡張しているためである。将 来, 携带電話のカメラが高速撮影にも対応すれば, この ような情報提示も有効な選択肢になってくるだろう.

また，別のアプリケーションとして，部屋を歩き回る ロボットに高速カメラを搭載し, その行動を制御するよ うな応用が考えられる。ロボットを制御する方法はほか にも考えられるが，その多くが，位置計測に基づくコン ピューティングの枠組みにとらわれている，例えば「映 像中のこの部分を指さして」といった指示を出すには, その映像自身に誘導信号を宿らせる本手法が有効と考え られる。

\section{4 今後の課題}

画素単位で可視光通信を行う新たな映像プロジェクタ について概説した. PVLC プロジェクタを用いることに より，実空間を不可視で動的な情報で満たすことができ

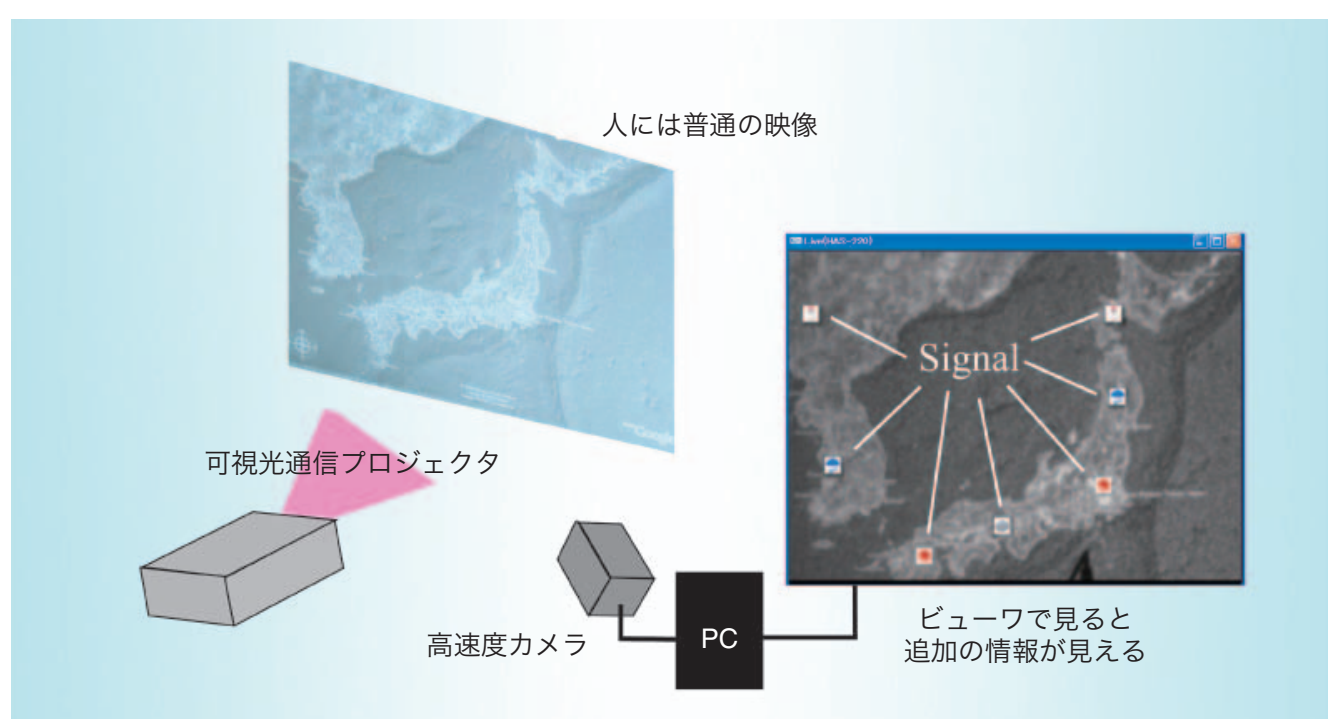

図 12 高速カメラによる付加情報のスーパインポーズ表示 
る、実空間に宿された情報にアクセスするためには，受 光素子や高速カメラなどを用いる。複雑な計算は要さず に，空間的に整合した情報の提示が可能になっている.

この方式では, 画素の輝度値に応じて伝送できる情報 の量が規定されることになる，今後，送りたい情報の量 と映像品質のトレードオフを見極めていく必要がある. 更に, 高速点滅が人に知覚されない条件についても検討 の余地がある。また，数画素をブロックとして扱うこと で, 情報をパラレルに伝送する方式や, 周辺画素でエラー 訂正を行うことでノイズに強い伝送方式を確立すること も今後の課題として挙げられる.

\section{4.むすび}

Ubiquitous Computing が揭げた invisible な情報環境 の構築を目指し, 実空間に情報を宿す試みを紹介した。 従来の「位置計測に基づくコンピューティング」に対し て, シンプルな構成であるがゆえに高速性を確保しやす く，ユーザ数や端末数が増加しても影響を受けないとい う特徴を有する。もち万ん，どうしても正確な位置計測 を行わなければならないアプリケーションも存在するだ ろう。必ずしもその必要のない, 若しくはそれ以上に高 速性や多数への対応が望まれるアプリケーションでは, 本論文で述べた「情報を宿す」アプローチを選択肢の一つ に加える意義はあるものと考えられる。

最後に, u-soul は吉野祥之君, PVLC プロジェクタは 北村匡彦君と木村翔君が精力的に取り組んできた研究課 題であり, 本論文の執筆には欠かせない貢献があった。 ここに感謝の意を表する。

\section{文献}

[1] M. Weiser, "The computer for the twenty-first century," Scientific American, vol.265, no.3, pp.94-104, 1991.

[2] 前田英作, 南 泰浩, 堂坂浩二, “妖精・妖怪の復権一新し い「環境知能」像の提案, ” 情報処理, vol.47, no.6, pp.624640, 2006

［3］苗村 健, “実世界に情報を宿す拡張現実型情報提示手法の 検討, ”信学技報, MVE2006-63, 2006.

４］畠山卓朗, 伊藤啓二, 白鳥哲夫, 城口光也, 久良知國雄, 春日正男, “音声歩行案内システム, ”情処学研報, 99-HI-82, vol.99, no.9, pp.35-40, 1999.

[5] 西村拓一, 中村嘉志, 伊藤日出男, 山本吉伸, 中島秀之, “イ ンタラクティブ情報支援のための無電源小型情報端末, ”イ ンタラクション2003, pp.163-170, 2003

[6] R. Kawano, Y. Matsuya, T. Ishihara, J. Inoue, and Y. Kado, "Voiceubique: Ultra-small high-quality infrared audio receiver," International Conference on Consumer Electronics 2005, vol.8, no.12, pp.285-286, 2005.

[7] 新居英明, 橋本悠希, 稲見昌彦, 渡邊淳司, “頭部方向指向 性を持つ見通し距離会話システム,”日本バーチャルリアリ ティ学会論文誌, vol.12, no.3, pp.401-404, 2007.

[8] 西村拓一, 中村嘉志, 常盤拓司, 伊藤日出男, 中島秀之, 小山慎哉, 矢入（江口）郁子, 猪木誠二, “音源定位 CoBIT の提案と視覚 CoBIT の実装, ”情処学研報, 2004-UBI-3(13), vol.2004, no.4, pp.85-92, 2004.

[9] M. Morimoto and Y. Ando, "On the simulation of sound localization,” J. Acoust. Soc. Jpn.(E), vol.1, no.3, pp.167 $-174,1980$.

［10］吉野祥之，橋田朋子，苗村 健，“超音波を用いた実音場の 拡張に関する基礎検討,”FIT2006 第 5 回情報科学技術 フォーラム 情報科学技術レターズ, vol.5, LK-008, pp.287 $-288,2006$.

[11］吉野祥之, 苗村 健, “u-soul: 超音波を用いた空間的な音像 提示システム, ”日本バーチャルリアリティ学会論文誌, vol.13, no.2, pp.239-246, 2008.

[12] J. L. S. Bellin and R. T. Beyer, "Experimental investigation of an end-fire array," J. Acoust. Soc. Am., vol.34, no.8, pp.1051-1054, 1962.

[13］合志和洋, 可児久昇, 宅野慎二, 田所嘉昭, “視覚障害者の ための超音波によるサインポストの検討, ”信学技報, ET97-72, 1997.

[14］吉野祥之, 苗村 健, “u-soul applications: 超音波を用いた 空間的な音像提示システムの応用, ”信学技報, MVE 2007-85, 2008.

[15］黒川高弘, 高橋甲介, 中西英之, “床面 RFID センサ「インテ リマット」の開発, ”情処学研報, 2007-HCl-124, pp.4956, 2007.

[16] R. Raskar, P. Beardsley, F. van Baar, Y. Wang, P. Dietz, J. Lee, D. Leigh, and T. Willwacher, "RFIG lamps: Interacting with a self-describing world via photosensing wireless tags and projectors," ACM Trans. Graphics, vol.23, no.3, pp.406-415, 2004.

[17］暦本純一, “2 次元マトリックスコードを利用した拡張現実 感の構成手法,” WISS1996, pp.199-208, 1996.

[18] H. Kato, M. Billingfurst, I. Poupyrev, K. Imamoto, and K. Tachibana, "Virtual object manipulation on a table-top AR environment," International Symposium on Augmented Realiy (ISAR2000), pp.111-119, 2000.

[19）中里祐介, 榊原誠之, 横矢直和, “不可視マ一力を用いたウェ アラブル AR システムの実環境における実証実験,”画像の 認識・理解シンポジウム（MURU2005）講演論文集, pp. 1420-1427, 2005.

[20] Y. Kakehi, T. Hosomi, M. Iida, T. Naemura, and M. Matsushita, "Transparent tabletop interface for multiple users on lumisight table," First IEEE Int. Workshop on Horizontal Interactive Human-Computer Systems (TableTop2006), pp.141-148, 2006.

[21] http://www.grid-mark.co.jp/gridonput.html

[22］稲見昌彦，杉本麻樹，新居英明，“Display-Based Computing の研究第一報：画像提示装置を主体とした実世 界指向情報システム, ”VR 大会, pp.441-442, 2005.

[23] T. Nishimura, H. Ito, Y. Nakamura, and H. Nakashima, "A compact battery-less information terminal for interactive information support," Ubicomp2003 Workshop: MultiDevice Interfaces for Ubiquitous Peripheral Interaction, 2003.

[24]白井良成, 松下光範, 大黒 毅, “秘映プロジェク夕: 不可 視情報による実環境の拡張, ”WISS2003, pp.115-122, 2003.

[25] J. C. Lee, S. Hudson, P. Dietz, "Hybrid infrared and visible light projection for location tracking," Symposium on User Interface Software and Technology (UIST), 2007.

[26］木村 翔，筧 康明，苗村 健，“赤外可視変換素材を用い た選択的情報提示に関する基礎検討,”FIT2006 第 5 回情 報科学技術フォーラム情報科学技術レターズ, vol.5, LK-009, pp.289-291, 2006.

[27］北村匡彦，苗村 健，“DMD を用いた空間分割型可視光通 信の基礎検討, ” FIT2006 第 5 回情報科学技術フォーラム 情報科学技術しターズ, vol.5, LK-010, pp.293-295, 2006.

[28］北村匡彦, 苗村 健, “DMD を用いた空間分割可視光通信： メタメディア情報を埋め込んだ映像投影, ”VR 論, vol.12, no.3, pp.381-388, 2007.

[29] Y. Tanaka, S. Haruyama, and M. Nakagawa, "Wireless optical transmission with the whitecolored LED for the 
wireless home links," PIMRC 2000, pp.1325-1329, 2000.

[30］新居英明, 稲見昌彦, “再帰性光通信技術の研究, ” VR 大会, pp. 539-542, 2003.

[31] I. E. McDowall, M. T. Bolas, P. Hoberman, and S. S. Fisher, "Snared illumination," ACM SIGGRAPH2004 Emerging Technologies, 2004.

[32] D. Cotting, M. Naef, M. Gross, and H. Fuchs, "Embedding imperceptible patterns into projected images for simultaneous acquisition and display, International Symposium on Mixed and Augmented Reality (ISMAR2004), pp.100-109, 2004.

[33] A. Grundhofer, M. Seeger, F. Hantsch, and O. Bimber, "Dynamic adaptation of projected imperceptible codes," International Symposium on Mixed and Augmented Reality (ISMAR07), pp.181-190, 2007.

[34] Q. Chen and T. Wada, "A light modulation/demodulation method for real-time 3D imaging," IEEE 3DIM 2005, pp. 15-21, 2005.

[35] A. Jones, I. McDowall, H. Yamada, M. Bolas, and P. Debevec,"An interactive 360 light field display," ACM SIGGRAPH2007 Emerging Technologies, 2007.

[36] S. K. Nayar and V. Branzoi, "Programmable imaging: Towards a flexible camera," Int. J. Comput. Vis., vol.70, pp.7-22, 2006

[37] D. Dudley, W. Duncan, and J. Slaughter, "Emerging digital micromirror device (DMD) applications," SPIE Proc., vol.4985, 2003.

[38] http://www.marubun.co.jp/product/semicon/display/ qgc18e0000001sjv.html

[39] S. Kimura, M. Kitamura, and T. Naemura, "EmiTable: A tabletop surface pervaded with imperceptible metadata," 2nd Annual IEEE International Workshop on Horizontal Interactive Human-Computer Systems (Tabletop 2007), pp.189-192, 2007.

(平成 20 年 3 月 3 日受付)

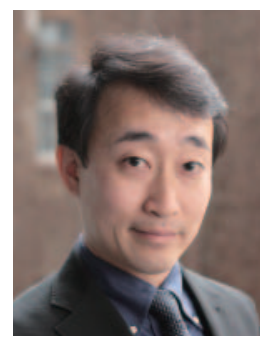

\section{苗村健 (正員)}

> 1992 東大·工・電子卒. 1997 同大大 学院博士課程了. 博士 (工学). 2000 米国 スタンフォード大学客員助教授（日本学術 振興会海外特別研究員)。2002 東京大学大 学院情報学環助教授. 現在, 同大学院情報 理工学系研究科准教授. 本会ヒューマンコ ミュニケーショングループ庶務監事 (2005 〜 2006), マルチメディア・仮想環境基礎 研究委員会副委員長 (2008). 日本バーチャルリアリティ学会理事・ アート\&エンタテインメント研究委員会委員長. 物理現象 (光学現 象) と情報処理の組合せによる実世界に根ざしたメディア技術の研 究に従事. 文部科学大臣表彰若手科学者賞 (2008), 情報科学技術 フォーラム FIT2006 船井ベストペーパー賞（2006）, NHK デジタ ルスタジアムゴールデンミューズ (年間最優秀作品賞) (2004), 日 本バーチャルリアリティ学会論文賞 $(2006,2007)$ など各賞受賞. 